\title{
Interpretations of Mohism's “Impartial Love" in the Republic of China: A Comparative Approach to Confucianism and Mohism
}

\author{
Ding Sixin 丁四新 \\ Professor of Department of Philosophy, Tsinghua University, Beijing, China \\ dingsixin@tsinghua.edu.cn \\ $W u$ Xiaoxin 吳曉欣 \\ Assistant Professor of Marxism School, Hunan University, Changsha, \\ Hunan, China \\ wxxmeng@126.com
}

\begin{abstract}
Since the reign of Qianlong and Jiaqing in the Qing dynasty, there have been signs of a resurgence of interest in Mohism. Intellectuals became particularly invested in Mozi's teachings during the period of the Republic of China. "Impartial love," the notion of equity advocated by Mozi, received the most attention. At the time, most discussions primarily attempted to respond to Mencius's criticism of Mozi's doctrine. Some scholars stressed Mohism's high regard for filial piety and demonstrated persuasively that the concept of impartial love did not closely correspond to Mencius's labelling of it as "disregarding one's father." Other scholars drew a distinction between Mozi and his disciples and identified only the latter as deserving of Mencius's criticism. Some thinkers affirmed impartial love's practical significance and saw it as a significant tool for condemning the autocracy and saving the country from imminent downfall. Others vehemently denounced the principle's impracticability. A close look at these different trends can provide us with a better understanding of the different attitudes of intellectuals in the period of the Republic of China regarding Confucianism and the relationship between Confucianism and Mohism.
\end{abstract}




\section{Keywords}

Confucianism and Mohism - impartial love - intellectual history in the Republic of China - Mencius - Mohism

Confucianism and Mohism were both established and became renowned schools of thought in the period that preceded the Qin dynasty [221-206 вСE]. Because Mencius [са. 372-289 вСЕ] believed that he should preserve Confucian tradition, he discredited the precept of "impartial love" [jian'ai 兼愛] promoted by the Mohists by accusing Mozi 墨子 [ca. 468-376 вСE] of disrespecting his own father and by describing the behavior he advocated as "bestial." In the History of the Former Han Dynasty [Han shu 漢書], it is written that, since the Western Han [206 BCE-25], "The teachings of the Hundred Schools of Thought had been banned and the teachings of the Six Classics [Liu jing 六經] alone were to be praised and carried forward." From then on, the influence of Mohism declined, and Mencius's labelling of impartial love as disregarding filial piety and as bestial was impressed upon the erudite circles for centuries afterward. Although some scholars, such as Han $\mathrm{Yu}$ 韓愈 [768-824], Li Zhi 李䞇 [1527-1602], and Wang Zhong 汪中 [1745-1794], argued in favor of Mohism's impartial love, none of them could break through the conceptual conventions of Confucian orthodoxy. ${ }^{2}$ Only

1 Ban Gu 班固, Han shu 漢書 [History of the Former Han Dynasty], annot. Yan Shigu 顏師古 (Beijing: Zhonghua shuju, 1962), 212.

2 Han Yu wrote: "Confucius's love for the people knew no bounds and while he sought to be close to those who were exemplary in their benevolence [ren 仁], he also regarded boundless generosity when helping those in needs as a trait of the noblest of character. Is that not what impartial love is?" In highlighting similarities between the Confucian and Mohist schools, Han Yu attempted to defend Mohism and finally concluded: "Confucius needed Mozi and Mozi needed Confucius." See Han Yu 韓愈, “Du Mozi 讀墨子 [A Critique of Mozi]," in Han Yu quanji 韓愈全集 [The Collected Works of Han Yu], ed. Qian Zhonglian 錢仲聯 and Ma Maoyuan 馬茂元 (Shanghai: Shanghai guji chubanshe, 1997), 129. Li Zhi commented: "Impartial love is what we call mutual love. To instruct people to love each other mutually, how can that be considered as against the ideal of benevolence?" See Li Zhi 李䞇, “Mozi pi xuan 墨子批選 [Selected Criticisms of Mozi]," in Mozi daquan 墨子大全 [A Comprehensive Anthology of Writings on Mozi], ed. Ren Jiyu 任繼愈 and Li Guangxing 李廣星 (Beijing: Beijing tushuguan chubanshe, 2004), 6:556. Wang Zhong wrote: "Mozi is using the precept of impartial love to encourage all sons under Heaven to revere their fathers with filial piety and yet, he is being described as someone who disregards his father. This truly is unfair." See Sun Yirang 孫詒讓, Mozi jiangu 墨子閒詁 [Annotations on Mozi], annot. Sun Qizhi 孫 啟治 (Beijing: Zhonghua shuju, 2001), 670. 
during the Republic of China [1912-1949], when Western academic trends increasingly spread through the country and the corruption of the traditional Confucian system was laid bare, did Mohism's impartial love and Mencius's attacks on it become a topic of interest again.

According to Liang Qichao 梁啟超 [1873-1929], “The Mohist system of thought may have had ten guiding principles, but in reality, it emerged and developed from one fundamental notion alone: the concept of impartial love." ${ }^{3}$ Chen Guyuan 陳顧遠 [1896-1981] remarked: "At the heart of Mozi's political philosophy is the doctrine of impartial love."4 Yang Kuan 楊寬 [1914-2005] was a proponent of the same idea: "The key to Mohism is the concept of impartial love." ${ }^{5}$ During the period of the Republic of China, renewed interest in Mozi's central doctrine led to passionate debates among intellectuals.

This article centers on discussions of Mozi's impartial love and identifies four groups of intellectuals based on their divergent views and interpretations. Intellectuals in the first two groups have in common that they focused on Mencius's criticism. However, the first group believed that impartial love did not amount to disregarding one's father and rejected Mencius's argument, declaring it unfair. Intellectuals in the second group tended to agree with Mencius, yet saw a clear difference between Mozi and his disciples. These intellectuals thought that the Mohist disciples deserved Mencius's criticism but approved of the original meaning and intention of the concept of impartial love. The third and fourth groups of intellectuals were mainly concerned with the actual practicability of Mozi's impartial love. Thinkers in the third group stressed the practical significance of the concept and, more specifically, how it could be used in the context of their current undertaking, that is, the introduction of Western learning to Chinese society and taking down feudal autocracy. Intellectuals in the fourth group approached the topic from an all together different perspective and invalidated Mozi's impartial love, regarding it as completely impracticable.

3 Liang Qichao 梁啟超, “Mozi xue'an 墨子學案 [The Life and Thought of Mozi],” in Yinbing shi heji:Zhuanji 飲冰室合集.專集 [Collected Works from the Ice-Drinker's Studio: The Special Collection] (Beijing: Zhonghua shuju, 1989), 39:8.

4 Chen Guyuan 陳顧遠, “Mozi zhengzhi zhexue 墨子政治哲學 [The Political Philosophy of Mozi]," in Mozi daquan, 38:486.

5 Yang Kuan 楊寬, “Moxue fenqi yanjiu 墨學分期研究 [The Study of Mohism by Periods]," Xue heng 學衡 79 (1933): 32. 


\section{Impartial Love and Filial Love as Compatible Doctrines}

When Mencius attacked the Mohist teaching of impartial love for its being unfilial, what he was fundamentally against was the proposition that other people's and one's own parents deserve the same amount of consideration. According to Mencius, this proposition disregarded the special status of fathers in Confucian ethics. Yet, during the period of the Republic of China, scholars pointed out that Mozi had not once denied the particular respect and care that children owe their parents and that, in fact, he did acknowledge the special social status of one's father. In the eyes of these intellectuals, Mencius's criticism appeared ill-founded. The reasoning of scholars such as Zhang Taiyan 章太炎 [1869-1936], Wu Leichuan 吳雷川 [1870-1944], Wang Zhixin 王治心 [1881-1968], Wu Feibai 伍非百 [189o-1965], Chen Guyuan, and Lang Qingxiao 郎擎霄 [b. 1903] may have differed to some degree, but their intention was basically the same: they all sought to speak in favor of the Mohist teaching of impartial love.

Zhang Taiyan's perspective on the topic of impartial love evolved over the years. Relatively early in the Republic of China, he turned his attention to the study of Mohist texts. He remarked at this point that

To indulge in defaming Mozi's impartial love, to call it "an utter disregard of one's father," the expression of such absurd opinions is not only characteristic of the youngest scholars still lacking in insight and experience, but it is also a statement that benevolent and exemplary people [junzi 君子] would not be able to take seriously, since it fails to grasp impartial love's real meaning.... Mohism attaches importance to both the patriarchal clan system and the worship of one's ancestors and sharply distinguishes between the ranks of the father and the son. If one advocates for the land under Heaven to be governed based on the rules of filial piety, how can we accuse this person of "failing one's father"? 6

This opinion, which Zhang expressed in the first block-printed edition of Words of Urgency [Qiu shu 訄書], reappeared in the second and revised edition of Words of Urgency and in Revised Views [Jian lun 檢論] (the renamed and revised edition of Words of Urgency), even though Zhang's position by

6 Zhang Taiyan 章太炎, Zhang Taiyan quanji 章太炎全集 [The Collected Works of Zhang Taiyan] (Shanghai: Shanghai renmin chubanshe, 2014), 7-8. 
then was more nuanced. In order to counter Mencius's accusations, Zhang referred to Mohism's sharp distinction between father and son and its advocacy of filial piety as a fundamental rule of governance. However, Zhang did not always hold steadily to his views. At times, his conviction also seemed to waver, and he almost agreed with Mencius. In his essay on "The Origins of Mohism [Yuan Mo 原墨]," which appeared in Revised Views, he declared: "Impartial love is the Way to be followed by a ruler in order to govern the country and ensure peace and stability. It is not a duty upon which common scholars and people are meant to conduct their actions." ${ }^{7}$ Mohism's impartial love was to be considered "the Way of the ruler" [renzhu zhi dao 人主之道] and not a rule of conduct to be put into practice by either the cultured or the ordinary. In "A Few Words about the Classical Schools [Zhuzi lüeshuo 諸子 略說]," Zhang also seemed to appreciate Mencius's argument to a certain extent, writing: "Impartial love is a duty to be assumed by the ruler of a country. Mozi himself was in no position to blindly implement this principle and that is why Mencius denounced his lack of consideration for filial piety." ${ }^{8}$ In Zhang's view, as a concept, impartial love was not problematic in itself; yet it remained a responsibility that could be assumed only by the supreme leader of a country. In other words, Zhang did not believe that Mencius had aimed to invalidate the impartial love doctrine completely. In his opinion, Mencius's concern had more to do with Mozi's behavior as an individual. Zhang Taiyan's opinion progressively changed from his defense of impartial love in the block-printed edition and the revised edition of Words of Urgency and in Revised Views and then, in "A Few Words about the Classical Schools," appeared to agree with Mencius's argument. In his later writings, Zhang went so far as to adopt the same position as Mencius, and he attempted to defend the Confucian master's views. This shift reflects, first, an evolution in Zhang's grasp of the concept of impartial love and, second, his changing attitude toward Confucianism and the study of Confucian classics. Zhang opposed Confucianism's standing as the sole orthodoxy to be revered, and he strove for an equal appreciation of all the classical schools of thought and their precepts. This is why, in both editions of Words of Urgency, a piece titled "Confucianism and Mohism [RuMo 儒墨]" appeared, in which Zhang considered both schools of thought equally. In fact, in "The Study

7 Zhang Taiyan, Zhang Taiyan quanji, 441.

8 Zhang Taiyan, Zhang Taiyan quanji: Yanjiang ji 章太炎全集.演講集 [The Collected Works of Zhang Taiyan: The Lectures] (Shanghai: Shanghai renmin chubanshe, 2015), 2:1015. 
of the Classical Schools of Thought [Lun zhuzi xue 論諸子學]," published in 1906, he addressed this issue directly:

Before the Spring and Autumn period, multiple schools of thought had yet to flourish. And after the reign of the Han Emperor Wu 漢武帝, only Confucius was to be revered. While there was no shortage of new schools that moralized eloquently, they had to do so by adhering to Confucian principles and not contradicting them. There were strained interpretations of quotations, their careless spread, increasing concessions to all kinds of doctrines, and even more deviations from the texts' original and true meanings and connotations. The more strained the interpretations, the more they went against the principles they meant to explain. ${ }^{9}$

When Zhang Taiyan published these words, he felt a strong admiration for the climate of the Spring and Autumn period $[770-476$ BCE], when various schools of thinkers lived among the people, regarded them as their equals, and freely debated their ideas. Zhang had little regard, however, for the intellectual conditions brought about by the Han dynasty [206 ВСЕ-220] and the unification of the country under Confucianism. As he yearned for the possibility that all schools of thought would be considered equally, he was bound to oppose Mencius's view of Mohism. Yet, after Words of Urgency was retitled Revised Views, not only did he change the title of the piece he had originally called "Confucianism and Mohism" to "The Origins of Mohism," but he also believed, as previously quoted, that impartial love "[was] not a duty upon which common scholars and people [were] meant to conduct their actions." He thereafter appeared skeptical of the Mohist project's scope of application. In his later years, Zhang went even so far as to express deep remorse over his early criticism of Confucianism, dismissing it as "insincere and presumptuous comments made more than a decade ago."10 His stance had changed completely, and he now considered himself part of the Confucianist guard.

By contrast, Christian theologists, such as Wu Leichuan (who also went by the name $\mathrm{Wu}$ Zhenchun 吳震春) and Wang Zhixin were steadfast in their defense of the Mohist doctrine of impartial love. Wu thought that Mencius denounced Mohism's disregard for filial piety merely to protect Confucian orthodoxy.

$9 \quad$ Zhang Taiyan, Zhang Taiyan quanji: Yanjiang ji, 1:48.

10 Zhang Taiyan, “Zhi Liu Yimou shu 致柳翼謀書 [A Letter to Liu Yimou]," in Zhang Taiyan zhenglun xuanji 章太炎政論選集 [Selected Political Writings of Zhang Taiyan], ed. Tang Zhijun 湯志鈞 (Beijing: Zhonghua shuju, 1977), 2:763. 
Wu also discredited Mencius's claims: "Such denigrating comments not only defy logic but are also poorly supported. This is not how scholars should acquit themselves." He also pointed out that, even though Mencius's view was purely subjective, it still had an extremely significant and lasting influence on subsequent generations of intellectuals. As a result, Mohism remained commonly censured for its perceived heterodoxy, whereas "The doctrine of impartial love did not go at all against the Confucian doctrines." Wu cites Mozi as emphasizing "the hierarchical order that must define relations between the ruler and the subject, between the superior and the subordinate and between the elder and the younger"ll to show that "there is absolutely no Mohist precept that advocates the eradication of the ancient hierarchical order."12 However, regarding the concept of "love," the views of Confucianism and Mohism differed in both scope and degree; Wu considered Mohism's “impartial love” closer in meaning to the Christian notion of "universal love." What Confucianism and Mohism had in common was beyond Wu's interest in the matter; after all, in his investigation of Mohism, his original intention had always been to connect Mohism and Christianity and to spread the Christian notion of love.

Wang Zhixin considered that Mencius's passionate attacks against Mohism's impartial love merely had to do with "a narrow-minded attempt at establishing his own school of thought." Based on the Mozi's section on impartial love, Wang Zhixin sought to demonstrate that notions of "filial duty" were indeed part of the Mohist project and that the main difference between Confucianism and Mohism was not in their discussions on filial piety but in the way in which they addressed performing filial duty. Both schools identified filial piety as the heart of ethics in the clan system. Hence, Mencius had no reason to declare that impartial love was bound to imperil filial piety. Wang Zhixin wondered: "Confucians thought that to perform filial piety was to act this way, Mohists thought it was to act that way. They defended different ways of being filial, but what was the point in claiming that Mozi was acting as if he had no father?" Even though Wang did not give any specific examples to support this supposed distinction between the schools' definitions of filial piety, it is possible to deduce what he meant by comparing the Analects and the Mozi 墨子. For Confucians, filial piety had to do with following every rule and performing every rite related to the life, death, and burial of one's parents or to the offering of sacrifices to

11 Here, Wu Leichuan is referring to the first passage in the second part of the "Shang Tong 尚同 [Upward Conformity]" chapter of the Mozi. - Trans.

12 Wu Leichuan 吳雷川, “Mo Di yu Yesu 墨翟與耶穌 [Mo Di and Jesus]," in Mozi daquan, 50: $177,234,25$ o. 
one's ancestors. In the "To Govern [Wei zheng 為政]" chapter of the Analects, Confucius is recorded as saying: "When parents are still living, they should be cared for and assisted according to the rules of propriety. After they have died, rules of propriety should again to be observed in carrying out the proper rites of burial and offering of sacrifice." Whereas parents were to be supported materially, Confucianism also emphasized the importance of respecting one's parents when caring for them. In the same chapter of the Analects, Confucius made the following remark: "Nowadays, people understand filial piety simply as being able to provide for one's parents' subsistence. Yet, this is something even dogs and horses can achieve. If one cannot show deference to one's parents, what is there to differentiate them from dogs and horses?" For Mohists, filial piety consisted of benefitting one's parents. In the first part of the section of the Mozi called "Canon [Jing 經]," it is defined as such: "Filial piety is to benefit one's parents." In comparison, Confucianism and Mohism clearly differed on this topic. Wang Zhixin's reasoning did not stop there. He added: "We can conclude that the general idea of the impartial love described by Mozi is similar to Christian love."13 When studying and interpreting the Mohist doctrine of impartial love, Wang's first objective had always been to connect the Mohist and Christian concepts of love, so as to identify the moment in Chinese history that could serve as an entry point for promoting Christianity. In sum, Wu and Wang's defense of impartial love was based on the exact same line of reasoning and shared the same objective, that is, to promote Christianity.

Another intellectual who defended Mohism and offered an analysis of impartial love was Wu Feibai 伍非百 [1890-1965]. In his view, Mohist impartial love emerged from the dynamic relationship between love [ai 愛] and benefit [ $l i$ 利]. He wrote about them: "Love is bound to embrace all of its object, but benefit does not have to. Therefore, love does not discriminate, while benefit does it to a great extent." Benefit was one of the main aspects of impartial love, yet it discriminated heavily. Therefore, it was impossible to equate impartial love with the kind of love that did not discriminate. That is why, in the end, Wu found Mencius's criticism to be unfounded: "Mencius failed to properly understand Mozi's original meaning. He grasped the mention of 'impartial,' but left out how it related to other precepts. He focused on the mention of 'love,' but he was unable to address the issue of benefit in a dialectical manner." Wu further defended Mohism's impartial love by differentiating between humans and animals. According to him, the fundamental difference between humans and animals was not found in how impartial their love was but,

13 Wang Zhixin 王治心, “Mozi zhexue 墨子哲學 [The Philosophy of Mozi]," in Mozi daquan, 33: 393, 410. 
rather, in their capacity to love. He declared: "Humans not only can show love for their own fathers, but also can love other people's fathers. This is what impartial love is. Beasts not only have no love for other people's fathers, but they also have no love for their own. Impartially, they do not love. Loving someone is something that humans are capable of. Loving nothing is what beasts do." Mencius could not see this. For this reason, Wu considered his attack on Mozi "the kind of fallacy where one pays too much attention to categories and fails to look with accuracy at what lies behind them."14 Wu set out to analyze the implied meaning of "impartial love." He arrived at the conclusion that impartial love had nothing to do with disregarding one's father, or to put it differently, that universal love did not oppose filial piety. He managed to debunk Mencius's criticism.

Chen Guyuan and Lang Qingxiao provide us with the last two analyses of Mohism's impartial love to be discussed in this section. Chen considered the doctrine of impartial love to be at the heart of Mozi's political thought. For Chen, the accurate implication of the doctrine involved both "a mutual and universal kind of love" and a "mutual interest in benefitting each other." Love meant to care for everybody; benefit meant to work for the greater good. Chen first drew a comparison with the Confucian ideal of datong 大同, or the Great Harmony, and then emphasized the importance and significance of Mohism's impartial love. He wrote: "Mozi may not have used the two characters of datong, but the real meaning of what has been recorded ${ }^{15}$ points to the ideal of Confucius's datong. Mozi uses the character jian 兼 for 'impartial,' which is actually far more realist than Confucius."16 This reasoning led Chen to reject the following remark by Shi Jiao 户佼 [39о-33о вСE]: "Confucius advocated for fairness and Mozi for impartiality, there is no difference between them."17 For Chen, "fairness" [gong 公] remained an empty

14 Wu Feibai 伍非百, “Mozi dayi shu 墨子大義述 [A Commentary on Mozi's Main Tenets]," in Mozi daquan, 27: 378-79.

15 Chen Guyuan seemed to refer to the following excerpt from the third part of Mozi's section on impartial love: "Today, I am adopting this principle to help the land under Heaven to rise and benefit from taking impartial love as a standard to govern. Then, with attentive ears and keen eyes, the people will assist each other in listening and seeing, they will assist each other with strengthened limbs and they will instruct each other diligently and in a good way. Thus the old and those with neither wife nor children will be looked after as long as they live, and the young, the weak and the orphaned will be cared for and be able to grow. These will be the benefits of governing according to impartial love." See Sun Yirang, Mozi jiangu, 116.

16 Chen Guyuan, "Mozi zhengzhi zhexue," 440.

17 Chen Guyuan's reference to the Shizi 尸子 [390-33о вСЕ] is inaccurate. The "Guang Ze 廣澤” chapter of the Shizi says: "Mozi revered impartiality and Confucius fairness, the 
slogan, while "impartiality" meant acting concretely. As an intellectual, Chen was, after all, a socialist, and he sought to connect the doctrine of impartial love to the doctrines of socialism. He wrote: "Mozi's doctrine of impartial love was already of great value for society back in his days. And even the last stages of socialism would not eclipse the importance and scope of impartial love."18 Lang Qingxiao was convinced that Mohism's impartial love could help end contemporary warfare. He argued: “Today's world has turned into a battlefield. If the nations that engage in warfare had the chance to hear of the doctrine of impartial love, they might cease their offensives and abandon their aggressive ambitions. So then, when the world would be full of compassion, the battlefield would turn into peace."19 Both Chen Guyuan and Lang Qingxiao opposed Mencius's remarks on Mozi. They shared the opinion that Mohism never attempted to challenge the moral principles governing families, may it be the filial piety or even the notion of benevolence [ci 慈]. However, their interpretations on the implications of disregarding filial piety differed. On the one hand, Chen Guyuan was convinced that impartial love did not amount to failing one's father. On the other hand, he described this lack of regard for one's father as an ideal so high that even Mohism could hardly claim to be able to attain it. He thus declared: "For Mencius to be cursing Mozi like this, saying that he is disregarding both his father and his ruler, today, that would simply be considered flattery!"20 In Chen's view, impartial love ought to achieve the

emperor reveres rectitude, Tianzi revered uniformity and Liezi humility, and the talented, they revere non being separated from others. For centuries, they have used their own doctrine to contradict each other, because in the end, they are all obsessed with their own ego and their prejudices and they cannot see clearly anymore.... If it were to be found that in essence, impartiality, fairness, humility, uniformity, rectitude, amiability, and the coexistence among all people, that all of these refer to the same idea, then there would be no case for mutual censure." See Li Shoukui 李守奎 and Li Yi 李軼, Shizi yizhu 尸子 譯注 [Translation and Annotation of the Shizi] (Harbin: Heilongjiang renmin chubanshe, 2003), 42.

18 Chen Guyuan, "Mozi zhengzhi zhexue," 519. Chen is not the only one to have brought up Mohism and socialism together during the period of the Republic of China. Liang Qichao, for instance, also wrote: "The art of governing according to Mozi has nothing to do with nationalism. It rather compares to cosmopolitan socialism." See Liang Qichao, "Zi Mozi xueshuo 子墨子學說 [The Teachings of Mozi]," in Yinbing shi heji: Zhuanji, 37:41. Zhi Weicheng 支偉成 [1899-1929] wrote: “Let us look at the socialist government of the working and peasant forces in today's Russia: it will prove that Mozi's doctrine was not simply a dream after all." See Zhi Weicheng 支偉成, Mozi zongshi 墨子綜釋 [Explanations of the Mozi] (Shanghai: Taidong tushu ju, 1925), 17. And in Yang Kuan's words: "In principle, Mohism is no different than today's socialism." See Yang Kuan, "Moxue fenqi yanjiu," 32.

19 Lang Qingxiao 郎擎霄, “Mozi zhexue 墨子哲學 [The Philosophy of Mozi]," in Mozi daquan, 32:551.

Chen Guyuan, "Mozi zhengzhi zhexue," 519. 
happiness of all members of society, and because it did not acknowledge partial love for one's parents, it ended up being described as failing one's father. This refusal to first pay respect to one's father was a socialist ideal that Chen particularly cherished, and because Mohists had not managed to achieve this ideal, he considered Mencius to have actually overestimated them. Liang Qingxiao thought that Mozi did not deserve the label that Mencius gave him: "Mencius defaming Mozi by saying he did not recognize his own father, [and] by accusing him of acting like a beast, that attitude was truly inappropriate."21 In sum, it appears that although they both rejected Mencius's criticism, Chen and Liang had a different understanding of what it meant. Chen's peculiar interpretation of the matter was mainly determined by his adherence to socialism.

\section{Two Kinds of Impartial Love: The Different Versions of Mo Di and His Disciples}

In contrast to the intellectuals discussed above who expressed outright opposition to Mencius's criticism, some thinkers distinguished between two kinds of impartial love. Although they thought that the kind advocated by Mozi did not in any way challenge the piety owed by children to their parents, they considered that the Mohist disciples who followed Mozi were to blame for their own lack of filial piety. Historically, this point of view was known as far back as Ban $\mathrm{Gu}$ 班固 [32-92], who lived during the Eastern Han [25-220]. In "The Bibliographical Treatise on Arts and Literature [Yiwen zhi 藝文志]" in the History of the Former Han Dynasty, Ban Gu remarked that Mohism cared to "provide for the virtuous and knowledgeable elders of society, and for this reason it promoted impartial love; ... it revered the patriarchal clan system and the rites regarding the offering of sacrifices, as well as the strict observance of the hierarchical relations between fathers and sons, and hence, it believed in the existence of ghosts and spirits; ... it considered filial piety to be the principle by which the land under Heaven ought to be governed and hence, it promoted conformity to one's superiors." In Ban Gu's interpretation, it was evident that the acknowledgment of family and blood ties is at the heart of the Mohist doctrines regarding the respect of ghosts and one's superiors. This seemed to be an aspect shared, to a certain degree, by the Mohist and Confucian ethics. Although Ban Gu made no mention of Mencius's criticism, it is hard to imagine Mencius attacking a Mohist doctrine whose theoretical foundations were similar to the that of Confucians. However, Ban Gu affirmed

21 Lang Qingxiao, “Mozi zhexue," 547. 
that later disciples of Mohism were the ones to blame for grossly distorting the original meaning of impartial love and for ruining the "harmonious" relationship that had once existed between Mohism and Confucianism: "Those inexperienced disciples purposefully decided to merely see frugality's positive aspects and so, they opposed traditional propriety and they blindly promoted impartial love's implicit meaning without aptly discriminating between those who are close to oneself by blood and those who are not."22

Because of the Mohists' overinterpretation, impartial love gradually diverged from the meaning originally attached to it, and it evolved into a doctrine that completely disregarded traditional propriety and family relationships. Han $\mathrm{Yu}$ inherited Ban Gu's views on the matter and wrote: "The debate actually arose from the later generations of Confucians and Mohists who competed to sell the teachings of their own masters and who failed to realize that the doctrines they promoted were already a far cry from the original meaning taught by Confucius and Mozi."23

Scholars such as Xie Wuliang 謝無量 [1884-1964] were impressed by Ban Gu and Han Yu's remarks and commended the original meaning of impartial love while drawing a distinction between Mozi and his successors. Xie Wuliang first pointed out that the love advocated by Mozi was different from the love of the Confucians: the former "was the kind of love that did not differentiate between close kin and distant relations, did not reaffirm the importance of hierarchical relations, and was given to all equally"; the latter "was a love offered according to how close or distant one's kin and relations were and where they stood in the hierarchy of relations." Based on their inner meaning and the forms they took, a close comparison could be made between impartial love and the Christ's universal love: after all, society's "greater good" was what they both sought to achieve. Following Ban Gu, Xie insisted that Mencius's accusations were "in fact, directed at the corrupt opinions of the later Mohists." In his opinion, a lot of passages in the Mozi stressed the importance of filial piety and highlighted love's key role in eradicating social conflict. Yet these passages could only be attributed to Mozi and what he first meant by "impartial love." The Mohists who came afterward completely cast aside impartial love's original meaning. It resulted in an altered doctrine that ignored the due respect one owes to one's parents. As a defender of Confucian orthodoxy, Mencius had absolutely no tolerance for schools of thought that tended to go in this way. This is why,

\footnotetext{
22 Ban Gu, Han shu, 1738.

23 Han Yu, "Du Mozi," 129.
} 
according to Xie, he 'took the Mohists' corrupt interpretations to an extreme and severely criticized them," ${ }^{24}$ initiating a cycle of violent attacks against the Mohists.

Sun Deqian 孫德謙 [1869-1935] and Chen Zhu 陳柱 [189o-1944] had a similar vision of the distinction between Mozi and the later Mohist disciples, but their reasoning was slightly different. Sun Deqian wondered: "Based on impartial love's original meaning, Mozi was instructing people to show filial piety to their fathers. To instruct them to be filial, is that not the complete opposite of Mencius's accusing him to 'act as if he was fatherless'?" In responding to this question, Sun first turned his attention to the word "master" (i.e., to the character $z i$ 子) as a way to refer to someone. According to Sun, Mencius's use of this term to refer to Mo Di 墨翟 revealed the respect that Mencius had for the philosopher, showing that Mencius never meant to deny Mo Di's authority. Sun goes further by highlighting the use of the character shi 氏 in the Mencius. The concept of impartial love is mentioned twice in the Mencius, but it is described slightly differently in both passages: the first points out the "impartial love of Mozi” [Mozi jian'ai 墨子兼愛] (in the first part of the “Jin Xin 盡心” chapter), the second discusses it as the "impartial love of the School of Mozi [Mo shi jian'ai 墨氏兼愛]” (in the last part of the “Teng Wen Gong 滕文公” chapter).

Sun interpreted the first passage as Mencius praising the spirit of Mozi's impartial love for everything under Heaven and he understood the second passage as a criticism of the Mohist disciples' unfilial behavior. In both, Mencius appeared to refer to the same "impartial love"; however, Mencius addressed the question differently, perhaps because of the distortion of the doctrine's original meaning by the Mohists. Regarding this, Sun added: "Not understanding that Mencius's criticism was aimed at the Mohists' disciples led to centuries of Mozi being unjustly interpreted."25 Sun's explanation seemed both to defend Mohism's impartial love and to protect Mencius's image as an enlightened figure of Confucianism. Nevertheless, the theoretical foundations on which it rested remain shaky at best, and therefore Sun's conclusion seems to be merely the result of personal opinion. ${ }^{26}$

24 Xie Wuliang 謝無量, Zhongguo zhexue shi 中國哲學史 [History of Chinese Philosophy] (Shanghai: Zhonghua shuju, 1926), 49-5o.

25 Sun Deqian 孫德謙, “Shi Mo jingshuo bian yi 釋墨經說辩義 [An Analysis on the Different Commentaries of the Mohist Canon]," Xue heng 學衡 25 (1924): 6.

26 Zheng Shiqu 鄭師渠 wrote: “Based on this new analysis, Mozi certainly can be cleared of the charges brought against him and the prestige of the Second Sage Mencius also manages to remain unblemished. Is that not getting the best of both worlds? It can be said of Sun Deqian that he really gave a lot of thought to the matter, but is this sort of pacifying 
Chen Zhu used the term shi 勢, which can mean a "force," a "power," or an "influence," to describe how the doctrine of impartial love evolved over the years after Mozi. Shi usually refers to a certain tendency in the development or transformation of something. Chen used this term to describe how the meaning of impartial love changed according to the different interpretations offered by Mohist disciples. Chen found a tendency in these thinkers' discourses, which he found dangerous in the way they portrayed "impartial love" for instance, to be "giving up on one's kin and not caring for them," "making the search for benefits the fundamental mission of life," or "loving only oneself." For Chen, this sort of thinking could bring chaos on earth. He thought that Mencius's analysis of these misinterpretations of Mozi's original doctrine was very perceptive: "Because he was afraid of the Mohists' corruption of Mozi's teachings and of the ways in which it could be disastrous for humanity, he felt he had to prove they were wrong." ${ }^{27}$ In reflecting on this topic, Sun Deqian and Chen Zhu brought up two very different concepts, but they held the same position regarding the distortion of impartial love by the Mohists. In addition to narrowing the object of Mencius's criticism, Chen concisely summarized the fundamental reasons for the divergence between Confucian and Mohist views: "The difference between Confucius and Mozi is that Mozi bases his doctrine on Heaven and Confucius on parents. ${ }^{28}$ More precisely, Confucianism considered filial piety the principle that governed the land under Heaven, and therefore it was more concerned with people's emotions than with reaping material benefits. The theories of Mohism, however, were founded on an emotionless Heaven, and this resulted in excessive emphasis on material gain and disregard for ordinary human feelings. This allowed Mohism to change its stance on certain issues easily, whereas Confucianism maintained the same principles over a long period. In the conflict between Heaven and one's parents, Chen saw the source of inspiration for both schools of thought, and he believed that this explained, above all, their different attitudes about human feelings and concrete benefits. It is quite obvious that, between these two schools, Chen Zhu was more inclined to endorse the Confucian perspective.

comment convincing at all?" See Zheng Shiqu 鄭師渠, “Xue Heng pai lun zhuzi xue 學 衡派論諸子學 [The Xue Heng Faction's Discourse on the Study of Classical Thought],” Zhongzhou xue kan 中州學刊, no. 1 (2001).

27 Chen Zhu 陳柱, “Dingben Mozi jiangu buzheng zixu 定本墨子閒詁補正自敘 [A Preface to the Definitive Emended and Annotated Mozi]," Xue heng 學衡 56 (1926): 2. 28 Chen Zhu 陳柱, “Moxue shi lun 墨學十論 [The Ten Credos of Mohist Philosophy]," in Mozi daquan, 37:151. 
In the face of cultural invasion from the West and the obvious corruption of the Confucian tradition, some factions of the New Culture movement attempted to find similarities between Mohism and Western civilization in order to foster a favorable environment for the spread of Western ideas in China. Others conjured up the doctrines and spirit of Mohism so as to attack the Confucian autocracy and to arouse the patriotic passion of their contemporaries in saving the country from imminent downfall. The concept of impartial love played a fundamental role in the New Culture movement's ideology, whether it was used to infuse a spirit of sacrifice in the people for the sake of others or to promote a doctrine that sought, essentially, to defend equality for all.

Yi Baisha 易白沙 [1886-1921] is representative of this movement to use Mohist teaching to save the country. Many references to Mohist doctrines as being able to "benefit one's compatriots" or to "rescue the nation" can be found in his writings. Yi endeavored to demonstrate how Mohist philosophy could have a positive influence on his contemporaries. He believed that the doctrines of "opposing aggression" [ fei gong 非攻], "moderating expenditure” [jie yong 節用], and “impartial love," which are part of the Mozi's "ten credos" [shi lun 十論], could play a crucial role in rejuvenating the Chinese nation and that even some of the other credos, such as "the will of Heaven” [tian zhi 天志] and “clarifying ghosts” [ming gui 明鬼], could benefit the common people. The modern scholar Ye Zongbao 葉宗寶 confirmed: "Without a doubt, what motivated Yi Baisha, when he set out to champion the Mohist philosophy, was his quest for a spirit that would help save the nation from its imminent downfall." 29 For Yi Baisha, China was in a state where "people were hardly able to show love for one another" and this would certainly lead to "general confusion, confrontations, pillages and the predatory invasion and occupation of China," chaotic circumstances that were rather similar to those depicted in the first part of the Mozi's section on impartial love. Yi insisted with a sense of urgency: "Impartial love cannot be delayed." 30 After all, he hoped that impartial love would end the conflicts and chaos afflicting his country.

29 Ye Zongbao 葉宗寶, “Lun Wu Si shiqi zun Mo yi Ru ji qi yuanyin 論五四時期尊墨抑儒 及其原因 [The Reasons of a Pro-Mozi Movement to Restrain Confucianism during the May Fourth Period]," Huanghe shuili zhiye jishu xueyuan xuebao 黃河水利職業技術學 院學報, no. 3 (2004).

$30 \quad$ Yi Baisha 易白沙, “Shu Mo 述墨 [On Mozi],” in Yi Baisha ji 易白沙集 [An Anthology of Yi Baisha], ed. Chen Xianchu 陳先初 (Changsha: Hunan renmin chubanshe, 2008), 55. 
In addition to regarding impartial love as a tool to help save the country, intellectuals in the New Culture movement also saw it as a powerful weapon against autocracy. Three lines of reasoning are found in their attempts to demonstrate the power of impartial love to dismantle the autocracy: first, they drew a clear distinction between Confucianism's hierarchical love and Mohism's impartial love so as to highlight the opposition between autocracy and equality; second, while offering a criticism of Mencius, they identified the differences in the basic principles between the Confucian and Mohist systems of thought; and, third, they underscored the compatibility of impartial love and bourgeois democratic ethics.

First, intellectuals in the New Culture movement saw a sharp difference between the filial love of the Confucians and the Mohists' type of love. Chen Duxiu 陳獨秀 [1879-1942] pointed out that "filial piety, as advocated by the Confucians, is different from the Mohists' type of love because it values the relative closeness or distance of one's kin, and respects hierarchy, and this is the chasm that separates Confucians and Mohists and that explains Mencius accusing Mozi of not caring for his father."31 Hu Shi 胡適 [1891-1962] held a similar opinion: "This doctrine of altruism contradicted Confucius's teaching that one ought to treat one's kin with kindness and generosity and not care so much for people who were not closely related to oneself." $32 \mathrm{Hu}$ also wrote: "Mohism's impartial love was rooted in the doctrine affirming the will of Heaven above all else. Originally, it meant that one must fully love and help others. It thus differs from the Confucians' superficial support of elders." 33 Chen and Hu differentiated between the Confucian and Mohist definitions of love, and both of them came to the conclusion that Mencius seized this difference as a pretext for attacking Mohism. Even though Hu never specifically addressed the merits and weaknesses of both schools of thought, his mention of Confucianism's "superficiality" suffices to reveal how unsatisfied he was with the hierarchical love of the Confucians.

31 Chen Duxiu 陳獨秀, “Xianfa yu Kong jiao 憲法與孔教 [The Constitution and Confucianism]," in Chen Duxiu zhuzuo xuanbian 陳獨秀著作選編 [Selected Works of Chen Duxiu], ed. Ren Jianshu 任建樹 and Li Yinde 李銀德 (Shanghai: Shanghai renmin chubanshe, 2014), 1:250.

32 Hu Shi 胡適, “Xian Qin mingxue shi 先秦名學史 [The Pre-Qin History of Logic]," in $H u$ Shi wenji 胡適文集 [The Collected Works of Hu Shi], ed. Ouyang Zhesheng 歐陽哲生 (Beijing: Beijing daxue chubanshe, 2013), 6:49.

$33 \mathrm{Hu}$ Shi, “Zhuzi bu chuyu wangguan lun 諸子不出於王官論 [On the Wise Thinkers of the Classical Schools Not Being Officials]," in Hu Shi wenji, 2:167. 
Second, intellectuals in the New Culture movement attempted to refute Mencius's arguments against Mohism's impartial love. Qian Xuantong 錢玄同 [1887-1939] wrote:

I believe that if we do not break away from the family as an institution, we are bound to fail at achieving happiness for all humanity. It is a completely absurd view that after we have broken away from our families, our parents and siblings will become like strangers to us. The issue of impartial love hints precisely at the need to let go of the family and the clan. Impartial love's objective is to teach people not to provide merely for one's parents and not to save their affection only for their children. How possibly can we consider this theory to be absurd? ${ }^{34}$

Qian clarified his argument by offering two more propositions. First, he considered the clan system of Confucianism detrimental to the development of individuals and society as a whole. Second, he thought that the Mohist doctrine of impartial love could play a fundamental role in freeing people from the shackles of the family and clan system. It was difficult to support the ancient system at that point, and "impartial love" was seen as a solution. Naturally, Qian remained unpersuaded by Mencius's vilifying remarks on impartial love. Yet, among the intellectuals in the New Culture movement, $\mathrm{Wu} \mathrm{Yu}$ 吳 虞 [1872-1949] clearly stood out as opposing Mencius's discourse on Mozi the most vehemently. Wu even devoted an essay to the topic, "Finding Fault with Mencius's Refutation of Yang Zhu and Mo Di [Bian Mengzi pi Yang Mo zhi fei 辨孟子辟楊墨之非]," in which he counterattacked Mencius's lambasting of the two other philosophers. To add weight to his argument that "impartial love" had absolutely nothing to do with a lack of filial piety, Wu quoted a passage from the third part of the Mozi's section on impartial love: "It is certain that if I first set out to love other people's close relatives and to care for their benefit, then they might reciprocate by loving my family and by caring for them." Wu commented: "The purpose of Mozi's impartial love is not merely to wish for other people to love our close relatives and care for their interests, it is about loving others' relatives and caring about their interests first. Only then may people care for ours in return. From this passage alone, it is already perfectly clear that impartial love can in no way be denounced as a lack of concern for one's parents." Wu based his analysis on his study of the Mozi, in which he found evidence that Mozi did not at all neglect the love one owes to one's own

34 Yang Tianshi 楊天石, ed., Qian Xuantong riji: Zhengli ben 錢玄同日記(整理本) [The Collated Diaries of Qian Xuantong] (Beijing: Beijing daxue chubanshe, 2014), 293. 
kin. Wu was adamant in his refutation of Mencius's criticism that followed his interpretation of the Mozi. Yet Wu also turned his attention to how impartial love was linked to some of the arguments found in Confucianism. He wrote:

In the Classic of Filial Piety [Xiao jing 孝經], Confucius is recorded as saying, "Respect shown to one's father makes all sons happy, respect shown to one's elder brother makes all younger brothers happy, respect shown to the ruler makes all subjects happy." The purpose here is the same as that of Mozi's impartial love. Mencius saying that "when one kills another person's father, this person may come and kill one's father and when one kills another person's brother, this person may come and kill one's brother"35 is also no different from Mozi's principle of impartial love. Does this mean that Confucius, too, should be criticized for disregarding his father, and that Mencius was actually posing as a "man without a father"? Mencius's criticizing of Mozi for the latter's supposed lack of filial piety fails to be supported by evidence, regardless of how hard Mencius attempted to justify it. ${ }^{36}$

Earlier, $\mathrm{Wu}$ demonstrated that, in Mohism, impartial love and lack of filial piety are completely unrelated. This could be described as a defensive tactic for countering Mencius's attack. This time, Wu penetrated deep into the territory of Confucian dogma and selectively picked out statements that agreed with the doctrine of impartial love so as to prove that Mencius's criticism of Mozi was an example of the Chinese saying that warns against crushing one's foot while trying to throw a rock at somebody else. Wu's tactic here should be seen as a direct offensive. Nevertheless, it must not be forgotten that bringing up the Classic of Filial Piety and excerpts from the Mencius might have been a convenient strategy for refuting Mencius's arguments, but it does not mean that Confucianism and Mohism are entirely equivalent. Like Chen, $\mathrm{Hu}$, and Qian, Wu Yu believed that an unbridgeable gulf existed between the Confucian and Mohist schools of thought: "At the most fundamental level, Mohist ideology absolutely cannot tolerate Confucianism. As for Mencius, his offensive against Mozi's impartial love and his accusations regarding filial piety are not

35 Here, Wu Yu is referring to a passage in the second part of the "Jin Xin 盡心” chapter of the Mencius. - Trans.

$36 \mathrm{Wu} \mathrm{Yu}$ 吳虞, $W u$ Yu ji 吳虞集 [An Anthology of $W u \mathrm{Yu}$ ], ed. Tian Miaomiao 田苗苗 (Beijing: Zhonghua shuju, 2013), 359. 
only in complete contradiction with Mozi's doctrine, but they also do not even slightly conform with logic."37

Finally, intellectuals in the New Culture movement were attracted by the notion of "impartial love" because of its practical significance. For this faction, the meaningful implications of impartial love transcended theory. Their interest in refuting Mencius's criticism had more to do with how impartial love seemed to agree with modern democracy and modern ethical ideals. In opposing Mencius, $\mathrm{Wu}$ also posed the following questions:

How could being "self-serving" [wei wo 為我] lead to a society without a sovereign? How could "impartial love" lead to a society that would not acknowledge fathers? That sort of illogical remark has long been ridiculed by scholars. And as for today's democratic nations, which, generally, do not have monarchs to speak of, can we really consider their citizens to be like the beasts cited by Meng Ke [Mencius] in his attempt to defame Mozi? ${ }^{38}$

In this specific passage, $\mathrm{Wu}$ seemed determined to undermine Mencius, but, in fact, he sought mainly to emphasize the fact that, whereas Confucianism could not possibly coexist with bourgeois democracy and republicanism, the doctrines of Yang Zhu 楊朱 [395-335 BCE] and Mo Di were perfectly compatible with contemporary democracy. In comparison with Wu, Qian Xuantong's way of addressing this issue was far more direct: "The ethics of imperialism are based on 'the fathers' affection, the sons' filial duty, the elder brothers' kindness, the younger brothers' deference, the husbands' righteousness, the wives' obedience, the elders' benevolence, the youths' compliance, the sovereigns' human-heartedness [ren 仁], and the subjects' loyalty. ${ }^{39}$ The ethics of the Republic should be based only on 'impartial love." 40 The dichotomy between "imperialist ethics" and "republican ethics" demonstrated clearly the conflict that existed between Confucianism's autocratic nature

37 Wu Yu, “Mozi de laonong zhuyi 墨子的勞農主義 [Mozi's Doctrine in Favor of the Working Class and the Peasantry]," in Wu Yuji, 82-83.

38 Wu Yu, “Jiazu zhidu wei zhuanzhi zhuyi zhi genju lun 家族制度為專制主義之根據論 [The Patriarchal Clan System as a Foundation for Autocracy]," in Wu Yuji, 11.

39 Here, $\mathrm{Wu} \mathrm{Yu}$ is referring to a passage in the “Li Yun 禮運” chapter of the Liji 禮記 [Book of Rites]. - Trans.

40 Qian Xuantong 錢玄同, “Fude Guoqing 賦得國慶 [Verses for National Day]," in Qian Xuantong wenji 錢玄同文集 [The Collected Works of Qian Xuantong] (Beijing: Zhonghua renmin daxue chubanshe, 1999), 2:210. 
and Mohism's egalitarian qualities. Chen Duxiu's perspective on the matter is again more detailed and precise:

If we are dissatisfied with the ethics of ancient times, it is because filial and fraternal piety are too narrow in scope. The Confucians uttered statements such as "love must be given according to status and hierarchy" or "love must be performed first toward one's own parents." That is too unreliable and hypocritical. In this ideal society of theirs, where "everyone would show filial obedience to their elder relatives and revere their elder brothers," strife would be far fiercer and fear far more widespread. Therefore, the modern ethical ideals serve to widen in scope the piety due to family and to exchange it for a universal and friendly affection for all members of society. ${ }^{41}$

It is quite obvious that the object of Chen's criticism was in fact the doctrine of filial and fraternal piety and its emphasis on status and hierarchy. Chen not only drew attention to the narrowness of this type of piety as well as to the excessively hypocritical love obliged by its hierarchy but also imputed the social conflicts looming on the horizon to the corrupt practices enabled by this set of beliefs. In his view, the solution was "to widen in scope the piety due to family and to exchange it for a universal and friendly affection for all members of society." Even though Chen did not provide a clear definition of what he meant by a "friendly affection for all members of society," it is easy to infer that he was referring to the Mohist philosophy of impartial love. ${ }^{42}$

When they set out to interpret the Mohist concept of impartial love, what the intellectuals in the New Culture movement first aimed to do was quite explicit: they wished to stress the autocratic flavor of Confucian hierarchical love and to use Mohist impartial love as a weapon to attack autocratic thinking. It might be inferred from this that there was no room for compromise between the Confucian and Mohist schools, yet, as was advocated, this perspective also

41 Chen Duxiu, "Xin wenhua yundong shi shenme? 新文化運動是什麼? [What Is the New Culture Movement?]," in Chen Duxiu zhuzuo xuanbian, 2:219.

42 Although Chen Duxiu highly regarded impartial love, he did not advise relying heavily on it. He demonstrated, in fact, a clear and perspicacious understanding of the issues raised by impartial love. Hence, he remarked: "If I devote myself to sacrificing myself and to benefitting other people, this would mean that I would be living for other people and not for myself. By no means is that the fundamental reason of living as an individual. Even Mozi's thinking cannot help but being too partial in the end." See Chen Duxiu, "Ren sheng zhen yi 人生真義 [The Real Meaning of Human Existence]," in Chen Duxiu zhuzuo xuanbian, 1:386. 
managed to conceal the relationship between the two systems of thought. Moreover, although these factions used impartial love to serve the patriotic objectives of a movement well anchored in reality and to connect it to the ethics of modern democracy, to a certain degree they also overlooked how their epoch differed from Mozi's.

\section{The Fierce Critics of Mohism's "Impartial Love"}

The "Geng Zhu 耕柱” chapter of the Mozi records a conversation between Wu Mazi 巫馬子 43 and Mozi. Wu Mazi believed it was impossible for him to love impartially. He explained: "I love the Zou people more than I love the Yue people, I love the Lu people more than I love the Zou, I love my fellow villagers more than I love the Lu people, I love my clan more than I love my villagers, I love my kin more than I love my clan, and I love myself more than I love my kin, because in the end, it is my own self who is the closest to me."44 Reflecting upon the relative intimacy and distance between people, Wu was convinced that the easiest love is the love that one has for oneself, because, after all, this is how most people are bound to feel. Under the Republic of China, intellectuals who opposed the concept of impartial love also centered their attention on its improbability. However, they based their arguments on slightly different grounds than Wu did. Three different types of arguments were made, each of which is covered briefly below.

Liang Qichao was one of the first to criticize Mohism's impartial love on the grounds that it was impossible to live up to. Still, Liang's study of Mohism should be divided into two distinct periods. ${ }^{45}$ Liang believed that impartial love was absolute and nonhierarchical. On this particular point, his position never changed. However, he once declared: "I would not hesitate to challenge

43 It is still hard to determine whether Wu Mazi should be considered Confucian. For the time being, we consider him simply an opponent of Mozi. On this topic, see Chris Fraser, "The Ethics of the Mohist Dialogues," in The Mozi as an Evolving Text: Different Voices in Early Chinese Thought, ed. Carine Defoort and Nicolas Standaert (Boston: Brill, 2013).

44 Sun Yirang, Mozi jiangu, 435 .

45 The first period corresponds to Liang Qichao's production of Xinmin congbao 新民 叢報 [New Citizen Journal], and representative essays of this period in regard to our topic were published in 1904: “Zi Mozi xueshuo," “Mozi zhi lunli xue 墨子之論理學 [A Neo-Confucian Approach to Mozi's Logic]." The second period corresponds to the 1920 and to works such as Mo jing jiaoshi 墨經校釋 [A Collection of Annotated Passages from the Mohist Canons], Mozi xue'an and Xian Qin zhengzhi sixiang shi 先秦政治思想史 [Political Thought of the Pre-Qin Period]. 
the opinions I expressed in the past based on the ideas I am defending today." 46 Although this remark makes clear his thinking evolved considerably over the years, his understanding of impartial love seemed to have changed the most. In "The Teachings of Mozi [Zi Mozi xueshuo 子墨子學說]," Liang not only compared impartial love to the love advocated by Jesus of Nazareth but also considered it diametrically opposed to Confucian hierarchical love. Moreover, he argued that impartial love was "merely a theory of perfection," that it was "absolutely impossible to achieve in reality" and that "it could not meet ethical standards." In contrast, he described the Confucian love as "the most effective way to maintain social order."47 For Liang, it was obvious that, in terms of how achievable it was, Mohist impartial love did not compare to Confucian hierarchical love. More than a decade later, in The Life and Thought of Mozi [Mozixue'an 墨子學案], although Liang still adhered to the Confucian definition of love - "the social organization of ancient times naturally did not allow it to be any different" - he also unexpectedly argued in favor of impartial love. Concerning Mencius's discourse on Mozi, he maintained: "If it did really manage to convey Mozi's spirit, it was not in manufacturing a bad name for it but, rather, in singing its praises." Indeed, he thought that Mencius's argument equating impartial love with failing one's father and with bestial behavior was entirely unfounded. The sharpest contrast between Liang's posture during that particular period and the one he had adopted earlier is found in how he newly addressed the topic of impartial love's practicability. He wrote: “Today's Russia is governed by the working class and the peasantry. Surely, this can be regarded as the partial realization of Mozi's ideal, which was for 'impartiality to take over status.' Whether or not the motives of the governing people of Russia are ethical, this is something on which I will not opine for the moment. It is already enough to highlight how this stands as a proof of Mozi's doctrine and how it contradicts the notion that 'though quite beautiful, impartial love is useless."'48 In the past, it sufficed for Liang to address impartial love's impracticability in theory only. Later in his life, he witnessed the success of the Russian Revolution and the establishment of its socialist regime, and he seemed to glimpse, amid all these changes, the achievement of impartial love. He hence came to believe that it was an attainable ideal. However, barely a year later, Liang rejected the doctrine outright again. Not only did he believe that Mencius's criticism was not meant "to be cruel," but he also declared Mozi's advocacy of impartial love

46 Liang Qichao, “Qingdai xueshu gailun 清代學術概論 [Introduction to Academia during the Qing Dynasty]," in Yinbing shi heji:Zhuanji, 34:63.

47 Liang Qichao, "Zi Mozi xueshuo," 37:34-35.

48 Liang Qichao, “Mozi xue’an,” 39:10, 70, 11. 
"impracticable, even though it remains a very desirable ideal."49 By then, Liang had returned to his former position on the topic. That for a short moment he defended the notion of impartial love and that he thought it to be practicable, this particular volte-face can be interpreted as a momentary response to the turbulent period he witnessed (and, more specifically, to the establishment of a communist regime in Russia). If he kept linking Mohism with the many new policies of the Russian socialist regime, it was only in order to identify a theory that would allow him to broach the latter topic. His first objective remained to launch a fierce attack on the revealed abuses of the socialist regime, by using the language of Mohist philosophy to do so. ${ }^{50}$ This explains why, in the brief interval of a year, Liang started to refute the achievability of Mozi's ideal again.

Qian Mu 錢穆 [1895-1990] and Guo Moruo 郭沫若 [1892-1978] also argued against Mohism's impartial love. Their arguments focused on the doctrine's contradictions, on which they wanted to shed some light in an effort to challenge the notion of impartial love all together. Qian regarded "impartial love" and the "exaltation of those with merit" [shangxian 尚賢] as the "two pillars" or the "main skeleton" in Mozi's teachings. He thought that, in advocating these two key principles, Mozi aimed fundamentally to spark "opposition to the nobility." Rebelling against the aristocratic class was a common concern in both Mohism and Confucianism; yet the two schools of thought differed in their understanding of rites and music. Through rites and music, Confucianism aspired to the restoration of the patriarchal clan system as it existed in the idealized period of the Xia [ca. 2070-16оо BCE], the Shang [16о0-1046 вCE], and the Zhou [1046-256 вС ] dynasties, and it challenged members of the nobility who frequently overstepped their authority. Mohism wished to overthrow the

49 Liang Qichao, “Xian Qin zhengzhi sixiang shi 先秦政治思想史 [Political Thought in the Pre-Qin Period]," in Yinbing shi heji: Zhuanji, 50:117.

50 In his later years, Liang Qichao rejected all of Mohism's notions of impartial love, material benefit, and social organization. He wrote: "Mozi wanted to break away from any kind of organization that implied the notion of 'private property.' Mozi's society of impartial love was to be organized in such a way that everything would be shared and enjoyed equally among all people" (in "Mozi xue'an," 10). "At no point did Mohism give thought to an individual in particular or did it consider people separately. What it referred to as 'benefit' is in fact the benefit of humanity as a whole. All individuals ought to sacrifice their own personal interest in order for the general interest to become apparent"; "In regard to social organization, standards for what are right and wrong are considered on the social level, not the individual level. This, too, is one of his theory's shortcomings. If we were to put it briefly, it would suffice to say that Mohism only acknowledged society and that it did not acknowledge the individual" (Liang Qichao, "Xian Qin zhengzhi sixiang shi," 122, 130). These excerpts make it clear that, in finding fault with Mohism, Liang fundamentally aimed to denounce the many abuses committed by Russia's socialist regime. 
nobility's authority by objecting to the practice of rites and music. Qian made the following comment regarding these different attitudes: "The Confucians were rightists only in standing against the nobility. But the Mohists were leftists themselves." ${ }^{51}$ When it came to the two movements' opposition to the nobility, Qian did not seem to take either of the two positions. Yet he remained steadfast in his criticism of Mohist doctrines. In response to statements in the Mozi addressing the paradox between the common people's general opposition to impartial love and their reliance on it where their own interests were concerned, ${ }^{52}$ Qian declared: "Everywhere on earth, the people do not agree to suffer for the sake of impartial love, but they willingly accept the happiness they can derive from other people loving impartially. When attempting to put Mohist thought into practice, this really remains an impossible problem to solve." Qian also quoted the section in the "Tian xia 天下” chapter in the Zhuangzi 莊子 that comments on Mozi's impartial love: "The person who instructs people to love as such, I am afraid they may not love others. For one's conduct to reflect this principle, one must not love oneself in the first place." Qian cites the Zhuangzi in order to support his own criticism of impartial love: "Originally intending to love all people, Mozi eventually turned toward misanthropic ways. This is why it is said that his intention was undermined by his behavior. Is that not another paradox of the deepest level found in Mohist philosophy?" Qian's general verdict regarding the Mohist teachings was that they had to contend with too many inherent contradictions. This was also the main criterion by which he assessed and compared the Confucian and the Mohist philosophies. As he put it, "Confucius is a harmony; Mozi is a tangle of conflicting ideas." ${ }^{53}$ On the one hand, Qian approved of the noble spirit and character that unfolded from Mohism's project of opposing the nobility. On the other hand, he was determined to expose the inherent contradictions of Mohism. In the end, that remained Qian's basic attitude toward Mohist philosophy in general. As for Guo Moruo, he concentrated his attention on the conflict between impartial love and social order as it is in reality. He wrote: "Mozi's biggest contradiction is in simultaneously admitting that all is governed by the antagonisms brought about by hierarchical order and telling people to

$51 \quad$ Qian $\mathrm{Mu}$ 錢穆, “Mozi 墨子,” in Qian Binsi xiansheng quanji 錢賓四先生全集 [The Collected Works of Mr. Qian Binsi] (Taipei: Lianjing chuban shiye youxian gongsi, 1998), 6:35.

This passage appears in the third part of the Mozi's section on impartial love: "One opposes impartial love in word yet favours those who love impartially when they are in need of help. Here, one's words and deeds definitely contradict each other." See Sun Yirang, Mozi jiangu, 118 . 
go ahead and be impartial." According to Guo, one could not abide by the premise that hierarchical social order and the conflicts it created were natural and then spread the catchphrase "impartial love." The Mohist doctrine was aimed at guiding society's unhappy majority in loving a minority of happy people. Whereas the latter enjoyed the former's love, they would only go so far as sharing a small percentage of their love. Regarding this, Guo was categorical: "This so-called impartial love is actually nothing but partial!"54 In Guo's view, "to love impartially" should have meant eradicating society's hierarchy and antagonisms; otherwise, because it remained partial, this type of love did not deserve to be called "impartial." In "A Critique of Confucius and Mozi [Kong Mo de pipan 孔墨的批判]," his criticism became even more incisive: “Mozi's idea of the people was that they remained the slaves they had been in ancient days, and his idea of material goods was also they were merely properties to be owned. Therefore, when he admonished the people to love other people, that is the same as urging them to love their oxen and horses."55 Many scholars used the terms "non-Mohist" or "anti-Mohist" to encapsulate Guo's stance against Mohism, and Cai Shangsi 蔡尚思 [1905-2008] even described him as a typical "admirer of Confucius and opponent of Mozi." ${ }^{6}$ In fact, Guo's mainly critical posture regarding Mozi became apparent only in the 1940s, as a result of the influence of Marxist historical materialism on his writings. However, Guo's attitude regarding Mohism was not always consistent. In his early years as a writer, in particular, he showed a certain inclination toward many aspects of Mohism, including its doctrine of impartial love, its chivalrous spirit, its religious thought, and elements of science and technology that were mentioned in the Mozi. ${ }^{57}$

Lastly, Liu Yizheng 柳詒徵 [188o-1956] focused his attention on one issue in particular: how the Mohist teaching of impartial love ran counter to the relationship between nature and human emotions. In comparison to the intellectuals mentioned above, Liu's criticism can be described as extreme to some

54 Guo Moruo 郭沫若, “Mozi de sixiang 墨子的思想 [Mozi's Thought],” in Guo Moruo quanji: Lishi bian 郭沫若全集: 歷史編 [The Collected Works of Guo Moruo: History Series] (Beijing: Renmin chubanshe, 1982), 1:471.

55 Guo Moruo, "Kong Mo de pipan 孔墨的批判 [A Critique of Confucius and Mozi]," in Guo Moruo quanji: Lishi bian, 2:114.

$5^{6}$ Cai Shangsi 蔡尚思, Shi jia lun Mo: Yaodian 十家論墨: 要點 [Ten Scholars on Mozi: The Key Points] (Shanghai: Shanghai renmin chubanshe, 2004), 8.

57 Cao Shunqing 曹順慶 and Nie Tao 聶鞱, “Shi xi 'fan shen lun' dui Guo Moruo moxue taidu de yingxiang: Cong 'yang Mo' dao 'fei Mo' 試析'泛神論'对郭沫若墨學態度的 影響: 從‘揚墨到‘非墨' [An Attempt at Understanding Pantheism's Influence on Guo Moruo's Research on Mozi: From Pro- to Anti-Mohism]," Beijing lianhe daxue xuebao 北京聯合大學學報, no. 4 (2014). 
degree. Liu considered impartial love impracticable at two levels. The first level, he argued, was that of nature. He wrote: "Whether it is one's grandparents or one's youngest sons, because they are naturally related to oneself, one's love for them comes instinctively; other people's elders and sons, because they are not naturally related to oneself, one instinctively feels separate from them." This was how he explained that, according to nature, one should differentiate between love for one's kin and love for others. The second level at which impartial love was impracticable had to do with the emotions of the majority of people. In Liu's view, people expressed concern and affection for others based on the degree of intimacy with them: "Emotionally speaking, people certainly do not treat others' places as they treat their own, they do not behave toward others' clans as they behave toward theirs; they do not regard others' nations as they regard their own." Because it contradicted people's nature and emotions, the doctrine of impartial love logically degenerated into an utter and dangerous lack of filial piety, and, in the end, it was indeed no different from the behavior of beasts. Obviously, Liu adamantly supported Mencius's arguments against Mozi's impartial love: "In this world, only beasts do not know that they have fathers. Only beasts and the kind of primitive people that resemble beasts in their way of living do not know they have fathers. That leads us to the direct conclusion that there is no other way to qualify Mozi's impartial love than to call it "bestial." Liu condemned all methods of blurring the line between one's own father and other people's fathers. He believed that being as filial as possible to one's father was part of a particular set of moral standards that enabled a desirable social order to be maintained. Based on this presupposition, he thought Mencius's criticism was "extremely incisive." Mohism, however, aimed only to obtain material gain: "I would seek to love and benefit other people's relatives only because other people would then love and benefit my relatives. If we look at this from the other way around, when other people would not care for my own and would not benefit them, then I would have to be allowed not to care for them in return." 58 In the end, Liu summarized his thoughts as follows: the most fundamental difference between Confucianism and Mohism was that the former taught about intention and the latter about utility and interest. Mohism might have appeared to be particularly concerned with people's emotions, but, in reality, as a whole it could only be harmful to humanity. In criticizing impartial love, Liu resolutely made common cause with the Confucians.

$5^{8}$ Liu Yizheng 柳詒徵, “Du Mo weiyan 讀墨微言 [A Few Words on Reading Mozi], Xue heng 學衡 12 (1922): 1-4. 


\section{Concluding Remarks}

In the Republic of China, an upsurge of interest in researching Mohism was sparked by the intensification of the assault on Chinese society of Western science and the steady revelation of corruption among the Confucian elites. During that period, the various debates that concerned Mohism also touched on the relationship between Confucianism and Mohism. Although Mencius criticized Mozi's impartial love for disregarding filial piety and for encouraging "bestial" behavior, his perspective on the topic did not seem to have had an important impact because he expressed it during the Warring States [475-221 BCE] period. In the two thousand years that followed, a few scholars, for diverse reasons, may have mentioned Mencius's extreme opinion of Mozi, but, in the end, no debate was generated. Only in the Republic of China did Mohist teachings, especially the core concept of impartial love, gradually become a topic of interest for intellectuals at the time, who first were spurred by the preoccupation with Mohism by Zhang Taiyan and Liang Qichao. Mencius's criticism had been essentially sparked by fundamental differences in the philosophies advocated by Confucians and Mohists. The opinions of intellectuals in the Republic of China reflected how they positioned themselves in the clash between these two schools of thought. These different postures, in turn, emanated from particular academic and political standpoints. Zhang and Liang both maintained a relatively complicated attitude toward Mohism's impartial love: although they both praised the principle at some point in their lives, in the end, their perspective was firmly aligned with Confucianism, and they both abandoned the idea of impartial love. Wu Leichuan, Wang Zhixin, Wu Feibai, Chen Guyuan, Lang Qingxiao, and the different factions in the New Culture movemen may have had different outlooks on the issue of impartial love, but they all attempted to defend Mozi's doctrine. Their respective motives ranged from a perceived need to promote Christian teachings to a desire to transform society. Regardless, they all expressed different attitudes toward the competing schools of Confucianism and Mohism, and toward Confucian tradition in general. Among the intellectuals opposed to the Mohist doctrine of impartial love, Qian Mu, Guo Moruo, and Liu Yizheng stood out for their strident views. Not only did they offer scathing criticisms of the doctrine, but they also categorically refused to acknowledge any connections or relationship between Confucianism and Mohism. In the end, the most moderate and generous among them were Xie Wuliang, Sun Deqian, and Chen Zhu, who all attempted to protect the image of Mencius while fighting for Mohism's impartial love to be considered and discussed again.

\section{Translated by Kathryn Henderson}




\section{Works Cited}

Ban Gu 班固. Han shu 漢書 [History of the Former Han Dynasty]. Annotated by Yan Shigu 顏師古. Beijing: Zhonghua shuju, 1962.

Cai Shangsi 蔡尚思. Shi jia lun Mo: Yaodian 十家論墨: 要點 [Ten Scholars on Mozi: The Key Points]. Shanghai: Shanghai renmin chubanshe, 2004.

Cao Shunqing 曹順慶 and Nie Tao 聶蓞. “Shi xi 'fan shen lun' dui Guo Moruo moxue taidu de yingxiang: Cong 'yang Mo' dao 'fei Mo' 試析‘泛神論’对郭沫若墨學態度的 影響: 從“揚墨, 到‘非墨' [An Attempt at Understanding Pantheism's Influence on Guo Moruo's Research on Mozi: From Pro- to Anti-Mohism]." Beijing lianhe daxue xuebao 北京聯合大學學報, no. 4 (2014): 76-84.

Chen Duxiu 陳獨秀. Chen Duxiu zhuzuo xuanbian 陳獨秀著作選編 [Selected Works of Chen Duxiu]. Edited by Ren Jianshu 任建樹 and Li Yinde 李銀德. Shanghai: Shanghai renmin chubanshe, 2014.

Chen Zhu 陳柱. “Dingben Mozi jiangu buzheng zixu 定本墨子閒詁補正自敘 [A Preface to the Definitive Emended and Annotated Mozi]." Xue heng 學衡 56 (1926): 1-7.

Fraser, Chris. "The Ethics of the Mohist Dialogues." In The Mozi as an Evolving Text: Different Voices in Early Chinese Thought, edited by Carine Defoort and Nicolas Standaert, 175-204. Boston: Brill, 2013.

Guo Moruo 郭沫若. Guo Moruo quanji: Lishi bian 郭沫若全集: 歷史編 [The Collected Works of Guo Moruo: History Series], vols. 1-2. Beijing: Renmin chubanshe, 1982.

Han Yu 韓愈. “Du Mozi 讀墨子 [A Critique of Mozi].” In Han Yu quanji 韓愈全集 [The Collected Works of Han Yu], edited by Qian Zhonglian 錢仲聯 and Ma Maoyuan 馬茂元, 129. Shanghai: Shanghai guji chubanshe, 1997.

$\mathrm{Hu}$ Shi 胡適. Hu Shi wenji 胡適文集 [The Collected Works of Hu Shi]. Edited by Ouyang Zhesheng 歐陽哲生. Beijing: Beijing daxue chubanshe, 2013.

Li Shoukui 李守奎 and Li Yi 李軼. Shiziyizhu 尸子譯注 [Translation and Annotation on the Shizi]. Harbin: Heilongjiang renmin chubanshe, 2003.

Liang Qichao 梁啟超. Yinbing shi heji: Zhuanji 飲冰室合集.專集 [Collected Works from the Ice-Drinker's Studio:The Special Collection], vols. 34, 37, 39, 5o. Beijing: Zhonghua shuju, 1989.

Liu Yizheng 柳詒徵. “Du Mo weiyan 讀墨微言 [A Few Words on Reading Mozi].” Xue heng 學衡 12 (1922): 1-5.

Qian $\mathrm{Mu}$ 錢穆. “Mozi 墨子.” In Qian Binsi xiansheng quanji 錢賓四先生全集 [The Collected Works of Mr. Qian Binsi], 6: 3-80. Taipei: Lianjing chuban shiye youxian gongsi, 1998.

Qian Xuantong 錢玄同. “Fude Guoqing 賦得國慶 [Verses for National Day]." In Qian Xuantong wenji 錢玄同文集 [The Collected Works of Qian Xuantong], 2: 209-13. Beijing: Zhonghua renmin daxue chubanshe, 1999. 
Ren Jiyu 任繼愈 and Li Guangxing 李廣星, ed. Mozi daquan 墨子大全 [A Comprehensive Anthology of Writings on Mozi]. Beijing: Beijing tushuguan chubanshe, 2004.

Sun Deqian 孫德謙. “Shi Mo jingshuo bian yi 釋墨經說辩義 [An Analysis on the Different Commentaries of the Mohist Canon]." Xue heng 學衡 25 (1924): 1-10.

Sun Yirang 孫詒讓. Mozi jiangu 墨子閒詁 [Annotations on Mozi]. Annotated by Sun Qizhi 孫啟治. Beijing: Zhonghua shuju, 2001.

$\mathrm{Wu} \mathrm{Yu}$ 吳虞. $W u$ Yuji 吳虞集 [An Anthology of Wu Yu]. Edited by Tian Miaomiao 田苗苗. Beijing: Zhonghua shuju, 2013.

Xie Wuliang 謝無量. Zhongguo zhexue shi 中國哲學史 [History of Chinese Philosophy]. Shanghai: Zhonghua shuju, 1926.

Yang Kuan 楊寬. “Moxue fenqi yanjiu 墨學分期研究 [The Study of Mohism by Period].” Xue heng 學衡 79 (1933): 1-47.

Yang Tianshi 楊天石, ed. Qian Xuantong riji: Zhengli ben 錢玄同日記 (整理本) [The Collated Diaries of Qian Xuantong]. Beijing: Beijing daxue chubanshe, 2014.

Ye Zongbao 葉宗寶. “Lun Wu Si shiqi zun Mo yi Ru ji qi yuanyin 論五四時期尊墨抑儒 及其原因 [The Reasons for a Pro-Mozi Movement to Restrain Confucianism during the May Fourth Period]." Huanghe shuili zhiye jishu xueyuan xuebao 黃河水利職業 技術學院學報, no. 3 (2004): 94-96.

Yi Baisha 易白沙. “Shu Mo 述墨 [On Mozi].” In Yi Baishaji 易白沙集 [An Anthology of Yi Baisha], edited by Chen Xianchu 陳先初, 55-72. Changsha: Hunan renmin chubanshe, 2008.

Zhang Taiyan 章太炎. Zhang Taiyan quanji 章太炎全集 [The Collected Works of Zhang Taiyan ]. Shanghai: Shanghai renmin chubanshe, 2014.

Zhang Taiyan 章太炎. Zhang Taiyan quanji: Yanjiang ji 章太炎全集·演講集 [The Collected Works of Zhang Taiyan: The Lectures]. Shanghai: Shanghai renmin chubanshe, 2015 .

Zhang Taiyan. “Zhi Liu Yimou shu 致柳翼謀書 [A Letter to Liu Yimou].” In Zhang Taiyan zhenglun xuanji 章太炎政論選集 [Selected Political Writings of Zhang Taiyan], edited by Tang Zhijun 湯志鈞, 2: 763-65. Beijing: Zhonghua shuju, 1977.

Zheng Shiqu 鄭師渠. “Xue Heng pai lun zhuzi xue 學衡派論諸子學 [The Xue Heng Faction's Discourse on the Study of Classical Thought].” Zhongzhou xue kan 中州 學刊, no. 1 (2001): 136-41.

Zhi Weicheng 支偉成. Mozi zongshi 墨子綜釋 [Explanations on Mozi]. Shanghai: Taidong tushu ju, 1925 . 